require a degree of proficiency and training not possessed by the ordinary employee. It was therefore held to be inconceivable that Congress, having given employees the express right to adjust grievances without the intervention of the bargaining representative, would deny them the best and most experienced representation in that adjustment.

Exclusive representation in the handling of grievances has long been one of the most valued rights of unions, for not only is the adjustment of any grievance likely to have some effect on the working unit as a whole, ${ }^{34}$ but it is also likely to produce the kind of immediate rewards for the aggrieved employee which will win his gratitude and future support. It was therefore natural that even under the limited interpretation of grievance adjustment, a certified union might strongly object to participation by its greatest rival in such negotiations. But under the rationale of the Court of Appeals for the Second Circuit, where disputes going to the root of the employment relationship have become proper subject matter for such grievance adjustment, it would seem that the objections of the certified union would be doubly strong. To permit a rival union to negotiate with respect to wages, hours, and general conditions of employment is to permit the kind of union rivalry which is so destructive to sound industrial relations. Competition between unions for the support of employees is necessary to representative unionism, but it has no place at the bargining table.

As for the employer, it might be argued that the Local 1250 decision will be a benefit because of his new opportunity to "play off" one union against another. But at the same time he will lose a large measure of the protection against damaging strikes by minority unions which he might have had by virtue of Section 8(b) (4) (c) of the Act. ${ }^{35}$ In a like manner, he will also lose the stability and security which could have been offered by the certified union under the Hughes Tool Co. decision. ${ }^{36}$

\title{
FREE SPEECH vS. THE FAIR TRIAL IN THE ENGLISH AND AMERICAN LAW OF CONTEMPT BY PUBLICATION
}

The contrast is striking between the English law of contempt by publication, ${ }^{\mathbf{x}}$ which is both clear and consistently enforced, and the heterogeneous law and

${ }^{34}$ Even the adjustment of the most personal grievance is likely to set a precedent for the established working conditions of the future. See Settling Plant Grievances, Div. of Labor Standards, Bulletin No. 60, at 37-38 (U.S. Dept. of Labor, 1943).

${ }_{35}$ See 63 Harv. L. Rev. 36 r, 362 (1949), noting the Local 1250 case.

${ }^{36} \mathrm{It}$ is well recognized that the employer usually gains, by virtue of collective bargaining, certain stability of wages, security against work stoppages, and the promise of a constant supply of trained workers. See Williamson and Farris, Trends in Collective Bargaining 215-I7 (x945).

I The term "publication" is used herein in the broadest sense to include not only newspaper articles but also radio broadcasts, Baltimore Radio Show, Inc. v. State, 67 A. 2 d 497 (I949), cert. den. 70 S. Ct. 252 (I950), conversation, Robinson v. City Court, I85 P. 2 d 256 (I947), posted notices, Butler v. Butler, ${ }_{3}$ P.D. 73 (1888), pamphlets, State v. Shumaker, 200 Ind. $623,{ }_{57}$ N.E. $769, x_{2}$ N.E. 44 I, I6 3 N.E. 272 (I927), and theatrical exhibits, Rex v.Williams and Romney, 2 L.J. (O.S.) 30 (K.B., I823). 
practice in America. The English courts very strictly curtail all comment regarding a pending trial, save only a fair and accurate report of the proceedings. They further claim, though seldom exercise, the power to punish abusive attacks upon the court even though not designed to influence any particular action. The American courts, on the other hand, have shown little diligence in preventing irresponsible interference with pending trials. ${ }^{2}$ When they have asserted their power, they have done so more to vindicate their dignity than to protect the rights of the litigants. ${ }^{3} \mathrm{~A}$ few states assert the common-law power to punish for insulting and defamatory remarks about the court even though not related to a pending action, 4 but the largest number have rejected this exercise of the contempt power. ${ }^{5}$ In a few states, ${ }^{6}$ and for the federal courts, ${ }^{7}$ statutes go so far as to abolish altogether the court's power to reach these constructive contempts.

This diversity in the approach of the English and American courts originates from the fact that in this area two cherished principles of Anglo-American law conflict-free speech and the fair trial. The English courts give almost complete precedence to the importance of preventing even the slightest interference with their work. ${ }^{8}$ The American courts, in contrast, place their emphasis on the importance of untrammeled expression. Constitutional principles of republican government and free speech are felt to require at least that the work of judges be

\footnotetext{
2 They have frequently been criticized for their laxity. See Taft, Criminology 204 (1942); Consensus on Reform of Sensational Reporting, $20 \mathrm{~J}$. Am. Jud. Soc. 83 (1936); Recommendations of Special Committee on Ways of Curbing Excessive Publicity in Connection with Criminal Trials, 22 A.B.A.J. 79 (1936); Robbins, The Hauptmann Trial in the Light of English Criminal Procedure, 2I A.B.A.J. 3or (1935); Perry, The Courts, the Press, and the Public, I5 J. Am. Jud. Soc. I39 (r932); Garner, Trial by Newspaper, I J. Crim. L. 849 (IgrI); Forrest, Trial by Newspaper, 14 Crim. L. Mag. 550 (1892).

${ }_{3}$ See Nelles and King, Contempt by Publication in the United States, $28 \mathrm{Col}$. L. Rev. 401,525 , at 545 (1928). The authors found that of fifty-eight contempt convictions to r928, in only fifteen did the publication relate to a case on or near trial before a petit jury, and only five of these might have interested the sensational press. Ibid., at 548 .
}

4 Note 21 infra.

$s$ Note 9 infra.

${ }^{6}$ For example, Ky. Rev. Stat. Ann. (Baldwin, I943) \& 432.240; Pa. Stat. Ann. (Purdon, I930) $\S \S 204 \mathrm{r}, 2044,2045 ;$ N.Y. Judiciary Law (McKinney, I948) § 750 (but permits punishment for false or grossly inaccurate report of proceedings). Some state courts, however, have held similar limiting statutes unconstitutional. The leading case is State v. Morrill, I6 Ark. 384 (1855). For other cases see Nelles and King, op. cit. supra note 3 , at 534-36.

7 Act of March 2, 183 I, c. 99,4 Stat. 487 , I8 U.S.C.A. $\$ \$ 401,402$, I503. For years the federal courts departed from the plain meaning of the statute and summarily punished constructive contempts. See Nelles and King, op. cit. supra note 3, at 430, 525. The practice was finally ended by the Supreme Court in r94r. Nye v. United States, 3 r 3 U.S. 33 (I94r).

${ }^{8}$ The English rule is stated in such broad terms as, "calculated to prejudice a fair trial," Rex v. Daily Mirror, [I927] x K.B. 845, 850; or "calculated to obstruct or interfere with the due course of justice." Reg. v. Gray, [IgO) 2 Q.B. 36, 40. Lord Chancellor Hardwicke's often-quoted decision in Read's and Huggonson's Case, 2 Atk. 469, 47 I (r742), stresses that "[t]here cannot be anything of greater consequence, than to keep the streams of justice clear and pure, that parties may proceed with safety both to themselves and their characters." The courts have occasionally limited the exercise of the power where the contempt was considered merely technical. Reg. v. Payne and Cooper, [1896] I Q.B. 577, 58x; Hunt v. Clarke, 58 L.J. 490, 493 (Q.B., I889). 
open to unrestrained comment after the particular action has terminated, 9 and at most that the summary and arbitrary power to limit speech be abolished altogether. ${ }^{10}$ Reluctance to curtail discussion even with regard to pending trials stems from fear of the power, if not from respect for the rights, of the popular press. ${ }^{\text {II }}$

Within the last nine years the Supreme Court has placed new emphasis on the importance of free speech in its contest with the demands of a fair trial. In Bridges v. California, ${ }^{\mathrm{x}_{2}}$ Pennekamp v. Florida, ${ }^{\mathrm{x}_{3}}$ and Craig v. Harney, ${ }^{\mathrm{x}_{4}}$ the Court has introduced the clear-and-present-danger test as a constitutional limitation on the state's contempt power. No publication can be restrained unless it creates a clear and present danger of the disorderly or unfair administration of justice. ${ }^{\text {I5 }}$ This is a "working principle that the substantive evil must be extremely serious and the degree of imminence extremely high before utterances can be punished." I6

These three cases today dominate the American law of contempt by publication. However, much of their implication remains to be worked out. Courts seeking to apply the clear-and-present-danger formula must necessarily base their conclusions on a careful analysis of the conflicting claims for preserving the functions of speech and for protecting the impartiality of the judicial process. Such an analysis will be suggested in this note. The study will draw upon relevant judicial precedent, both English and American. Points will be noted at which objective or psychological studies might help to support or correct the policy of the law. Lastly, the study will suggest at each stage the particular form in which the clear-and-present-danger test should be stated.

\section{I}

Comment on the work of a court not related to pending proceedings will range from the legal journal's calm discussion of the merits of a decision to a libellous attack upon the integrity of the judge. The English courts declare the right to honest criticism of the work of the court, but reserve the power to punish scandalous attacks upon the court itself. ${ }^{17}$ This power has been used

9 State v. Coleman, 347 Mo. I238, 1258, 152 S.W. 2d 640 (r94I); State v. Circuit Court of Eau Claire County, 97 Wis. I, Io, 72 N.W. I93, I95 (I897), and cases cited therein.

${ }^{10}$ See Nelles and King, op. cit. supra note 3 , at $4 \mathrm{r} 8$; editorial, Chicago Daily Tribune, part $\mathrm{r}$, p. 20, col. I (Feb. I, I950).

rx See Perry, The Courts, the Press, and the Public, I5 J. Am. Jud. Soc. I39, I42 (1932).

12314 U.S. 252 (I94I).

${ }^{{ }^{3}} 328$ U.S. 33 (I946).

${ }^{{ }_{4}} 33^{x}$ U.S. 367 (1947).

${ }^{15}$ Pennekamp v. Florida, 328 U.S. 331, 335 (1946).

${ }^{x 6}$ Bridges v. California, $3 x_{4}$ U.S. 252,263 (I94I).

${ }_{17}$ "Any act done or writing published calculated to bring a Court or a judge of the Court into contempt, or to lower his authority" is a contempt, with one "important qualification," that "[j]udges and Courts are alike open to criticism, and if reasonable argument or expostulation is offered against any judicial act as contrary to law or the public good, no Court could or would treat that as contempt of court." Reg. v. Gray, [rgoo] 2 Q.B. 36, 40. 
infrequently. A Privy Council dictum in I899 stated that "[c]ommittals for contempt of Court by scandalizing the court itself have become obsolete in this country," the courts preferring to leave the matter to "public opinion", ;8 but a case arising the following year ${ }^{\mathrm{I}}$ and a second in $x 9^{2} 8^{20}$ belie the complete accuracy of the statement.

A minority of American states follow the English rule in proclaiming the power to punish an abuse of the court even though not related to any pending proceeding. ${ }^{2 r}$ Contempt of court is sometimes simply defined as any publication which speaks of the court contemptuously.22 In practice the power is employed more frequently in America than in England, however. The probable explanation for this result is not that the English judges are less willing to suppress attack, but that they come in for considerably less intemperate criticism than their American brethren.23

No exercise of the contempt power has so little justification or is subject to so much abuse as that directed toward criticism not related to pending proceedings. This point has frequently been made by the American critics. ${ }^{24}$ The rationale for punishing abusive attacks upon the court is that they cause public dissatisfaction with the judiciary and the administration of justice, a result which discourages parties from bringing rightful claims to the courts, and ultimately leads men to take the law into their own hands. ${ }^{25}$ The countervailing

- ${ }^{8}$ McLeod v. St. Aubyn, [I899] A.C. 549, 56r. The court admitted, however, that conviction for scandalizing the court might be necessary in the colonies, but reversed on other grounds.

19 Reg. v. Gray, [1900] 2 Q.B. 36 . The newspaper article, published the day a trial for the publication of indecent and obscene matter ended, strongly criticised the judge for a lecture to the press at the commencement of the trial not to reproduce any of the offensive literature.

${ }^{20}$ Rex v. Editor of the New Statesman, 44 T.L.R. 301 (I928). Dr. Marie Stopes, an advocate of birth control, suffered a verdict against her in a libel action for suggesting that the Morning Post had suddenly refused to print her advertisements because of Roman Catholic influence. The New Statesman's article said, "The serious point in this case, however, is that an individual owning to such views as those of Dr. Stopes cannot apparently hope for a fair hearing in a Court presided over by Mr. Justice Avory-and there are many Avorys."

${ }^{21}$ State v. Shumaker, 200 Ind. 623, I57 N.E. 769, I62 N.E. 44I, I63 N.E. 272 (I927) (AntiSaloon League pamphlet charged that Supreme Court rule excluding evidence secured by unlawful search and seizure set many prohibition violators free, and accused judges of "wet" sympathies); Campbell v. Jeffries, 244 Mich. 165,221 N.W. I38 (r928) (charged that eminent domain case "smells to high heaven" because of high award and speed of decision); State v. Shepherd, I 77 Mo. 205, 76 S.W. 79 (Ig03) (charged Supreme Court was owned by railroads); State v. Morrill, 16 Ark. 384 (I855) (charged bribery); cases cited 6 R.C.L. 513 (I9I5).

$\approx$ A campaign circular charging that the nomination of an opponent was "not a nomination at all but the appointment by a corrupt and rotten court" is contemptuous because "necessarily offensive, insulting and contemptuous . . . and is calculated to create disregard for judicial authority." Lancaster v. State, 208 Ark. 4I2, r86 S.W. 2d 673, 675 (r945). Accord: Cormack v. Coleman, I20 Fla. I, I6r So. 844 (I935).

${ }_{23}$ Bryce, 2 The American Commonwealth 632 ( $3 \mathrm{~d}$ ed. 1908 ).

${ }^{24}$ Thomas, Problems of Contempt of Court 20, 35 (1934); Nelles and King, op. cit. supra note 3 , at $543-53$.

${ }^{25}$ See Cobb v. State, 59 Ga. App. 695, 70I, 2 S.E. 2 d II6, I20 (I939); Rex v. Davies, [Ig06] I K.B. 32,40 (I905). 
argument holds that the only way for the courts to secure this admittedly desirable public respect is to earn it by the ability, impartiality and essential justice of their proceedings; that if the courts are inefficient or corrupt, the best thing to do is quickly to expose the evil in order to eliminate it. ${ }^{26}$ Further, the temptation to abuse the contempt power, where the judge is both prosecutor and jury, is greatest when it is the judge himself, his colleagues, or his bench that has been attacked.

Even prior to the first of the Supreme Court triumvirate of cases, the majority of states held that this branch of the contempt power violated constitutional principles of free speech. ${ }^{27}$ Its abolition was made universal when the Supreme Court in the Bridges case categorically rejected "disrespect for the judiciary" as a substantive evil which would warrant any form of restriction upon speech. ${ }^{28}$

II

The strongest argument for limiting speech can be made with respect to those publications which interfere, or are likely to interfere, in some definite way with a pending trial.29 "Legal trials are not like elections to be won through the use of the meeting-hall, the radio and the newspaper," 30 but to be decided only upon "evidence and argument in open court." ${ }^{3 x}$ In England, all publications "calculated to obstruct or interfere with the due course of justice" are prohibited. ${ }^{22}$

${ }^{26}$ See Bridges v. California, 3 I4 U.S. 252, 270 (I94I); Storey v. People, 79 Ill. 45, 49 (I875).

${ }^{27}$ Note 9 supra.

${ }^{28}$ Bridges v. California, 3 I4 U.S. 252, 270 ( $(994 \mathrm{I}$ ).

${ }^{29}$ The question of when an action is pending for contempt purposes has engendered considerable discussion in the cases. The most extreme view holds that the matter is pending from the moment of arrest, Rex v. Clarke, I03 L.T.R. $6{ }_{3} 6$ (IgIo); or the hearing before the coroner's jury, Rex v. Fleet, x B. \& Ald. 379 (x8I8); or the filing of the complaint, Greenwood v. The Leather-Shod Wheel Co., Ltd., I4 T.I.R. 24 I (1898); until the expiration of the time allowed for moving to rehear the decision of the highest appellate court, In re Nelson, Io3 Mont. 43,60 P. 2d 365 (I936). It has been held contempt to hinder the work of a receiver appointed by the court pending an appeal of a partnership decision, Helmore v. Smith, 35 Ch. D. 449 (I886); or to criticize trustees appointed under a will, Ex parte Jones, 13 Vesey, Jr. 237 (r806). Some authorities forbid comment which may prejudice the trial of closely related actions. Ex parte Shuler, 210 Cal. 377, 400, 292 Pac. 48I, 49I (1930) ("more or less interlocked criminal actions"); State v. Shumaker, 200 Ind. 626, 157 N.E. 769 (1927) (criticism of court's refusal to admit evidence secured by unlawful search and seizure might prejudice its disposition of appeals from additional prohibition convictions then pending). Contra: State v. Coleman, 347 Mo. $x_{23} 8$, $1260, x_{2}$ S.W. $2 d$ 640, 649 (I94x) (holds that the right to criticize a closed case cannot be denied merely because there are other cases pending which involve the same party or a similar issue).

The liberal view ends the restriction after return of the jury's verdict, Dallas v. Ledger, 4 T.L.R. 432 ( 1888 ), and after the final disposition of any interlocutory matter. Pennekamp v. Florida, 328 U.S. $33^{\mathrm{I}}$ ( 1946 ) (quashing of indictments for insufficiency); Nixon v. State, 207 Ind. 426, r93 N.E. 59I (r935) (appointment of receiver); Storey v. People, 79 Ill. 45 (I875) (criticism of grand jury after return of indictment). Justice Frankfurter, speaking for the Supreme Court minority, feels that the question should be decided by the "substantial realities" of the case. Bridges v. California, 3I4 U.S. 252, 303 (I94I).

${ }^{30}$ Bridges v. California, 314 U.S. 252, 270 (I94I).

${ }^{3 x}$ Patterson v. Colorado, 205 U.S. 454, 462 (I907).

32 Reg. v. Gray, [I900] 2 Q.B. 36, 40. 
The American courts follow rules couched in similarly broad terms, but they have been much more sporadic in enforcing them. ${ }^{33}$ Perhaps in time the American courts will devote more attention to protecting the administration of justice from interferences of this kind. If they do, the newly introduced clear-andpresent-danger test will play a vital role in determining the limits of their power.

In reconciling the opposing claims of the fair trial and free speech, the clearand-present-danger test clearly favors the latter. In doing so, it treats all speech alike, whatever its purpose, or whatever the function it might perform. It can be questioned whether this is a realistic approach, inasmuch as the choice in the contempt area is not between free speech and some public convenience, but between "claims on behalf of freedom of speech [and] claims on behalf of liberties no less precious." ${ }_{34}$ The clear-and-present-danger rule has been criticized for its failure to distinguish between speech which serves a public function and speech which is merely the exercise of a private right. 35 The implication of such a distinction in the contempt area might be that public speech should be limited only when it creates a clear and present danger of severe interference, while speech which lacks a public function might be given less preferential treatment. The English law of contempt has used some notions of public speech to breach its otherwise solid wall of restraint. The public interest that no prosecutions be secret gives almost absolute protection to a fair and accurate report of all judicial proceedings even though such a report might interfere with the conduct of the trial. ${ }^{36}$ Recognizing the public service performed by the press in exposing fraud and crime, English courts have made an exception to their otherwise strict limitation of the press in one particular situation. They hold that the person whose undesirable activities have been exposed will not be permitted to cut off all further publicity merely by bringing a libel action against the harassing newspaper. ${ }^{37}$ An advertisement to secure evidence in a pending cause is not contemptuous if published in good faith and not merely to prejudice the op-

33 "IA]ny publication ... which concerns a case pending in court, and has a tendency to prejudice the public concerning its merits, and to corrupt the administration of justice, or which reflects on the tribunal or its proceedings, or on the parties, the jurors, the witnesses or the counsel, may be visited as a contempt." People v. Wilson, 64 Ill. I95, 213 (1872). Accord: State v. Edwards, I5 S.D. 383,89 N.W. Ior 1 (1902); 6 R.C.L. $5 \circ 9$ (Igr5).

34 Frankfurter, dissenting in Bridges v. California, 314 U.S. 252, 282 (194I).

35 Meiklejohn, Free Speech and Its Relation to Self-Government ( 1948 ).

${ }^{36}$ Rex v. Davies, [I945] I K.B. 435, 446 (I945). One instance has been discovered in which the right to make a fair report was suspended temporarily. Where several defendants were tried seriatim for high treason, it was held contempt to publish a report of the trial of the first two before the trial of the rest began, in violation of the judge's request not to do so. Rex v. Clement, 4 B. \& Ald. 218 (r82r).

${ }^{37}$ "The Court had to reconcile two things-namely the right of free speech and the public advantage that a knave should be exposed, and the right of an individual suitor to have his case fairly tried. The only way in which the Court could save both was to refuse an unlimited extension of either right. It became, then, a question of degree." Rex v. Blumenfeld, 28 T.L.R. 308, 3 II (IgI2). Accord: Rex v. Editor of the Daily Mail, 44 T.L.R. 303 (I928); In re Labouchere, I8 T.L.R. 208 (IgOI). 
ponent's case. ${ }^{38}$ As an example of private speech, on the other hand, the English courts have been quick to suppress sensational reporting of criminal proceedings in which the only aim is to increase the journal's circulation. ${ }^{39}$ The adoption by American courts of the distinction suggested by these precedents will help to modify the otherwise rigid result of the clear-and-present-danger test.

Turning to the trial side of the contempt problem, it can be seen that the publications which will interfere with the administration of justice are those which influence or obstruct the work of the persons who are an integral part of the judicial process--the judge, the parties, the witnesses and the jury. Who of these might be affected varies according to the different stages of the proceedings. A publication coming after the return of the indictment, the arrest, or the filing of the complaint might affect the parties (including the state prosecutor), the witnesses, and the prospective jurors. The selection of the jury reduces the indeterminate number of "prospective jurors" to twelve known persons who require special immunization from outside interference. During the trial, parties, witnesses, judge, and jury need protection. Attention focuses upon the trial judge alone while he is considering sentence or judgment, or a motion for a new trial. On appeal, and until the last moment for rehearing has expired, the appellate court becomes the object of possible influence. The English courts find contempt where there is the possibility of influencing any of these persons at any stage. Even beyond specific influence, any attempt to "prejudge" a trial,40 or to "prejudice the minds of the publick against . . . parties in causes," $4 \mathrm{r}$ is held contempt of court. The terms and spirit of the clear-and-present-danger rule, however, preclude such a broad approach. Specific evils must be found.

The Supreme Court decisions have particular application only to publications directed solely at the judge. $4^{2}$ In both Bridges v. California ${ }^{43}$ and Craig v. Harney4t the publication appeared while the trial judge was considering a motion for a new trial. The editorials in the Bridges companion case, Times Mirror Co. v. Superior Court, urged the trial judge to give maximum sentences in a case then

${ }^{8}$ Plating Co. v. Farquharson, I7 Ch. D. 49 (I88I); Butler v. Butler, I3 P.D. 73 (I888) (posters offering reward for evidence of wife's illegitimate pregnancy might not have been contemptuous if bona fide and not an attempt to discredit her in pending divorce proceedings).

39 Rex v. Bolam, Times (London) p. 3 (Mar. 26, I949); Rex v. Evening Standard, 40 T.I.R. 833,836 (1924); Rex v. Clarke, 103 L.T.R. 636,639 (rgIo).

$4^{\circ} \mathrm{Rex}$ v. Tibbits and Windust, [Igo2] I K.B. 77, 87; Rex v. Williams and Romney, 2 L.J. (O.S.) 30,3 I (K.B., 1823 ).

4x Read's and Huggonson's Case, 2 Atk. 469 (1742); Tichborne v. Tichborne, 39 L.J. (N.S.) 398 (Ch., I870).

${ }^{2}$ The offensive editorials in Pennekamp v. Florida, 328 U.S. 33 I (x946), criticized a judge for quashing rape indictments because poorly drawn. The publication could have been regarded as relating only to a closed matter, but the Court, viewing the state of Florida's case in the strongest light, treated the rape prosecutions as pending matters. It is difficult to see what the interference could be. Even Justice Frankfurter concurred.

${ }^{43} 3{ }^{14}$ U.S. 252 (I94I).

${ }^{44} 33$ I U.S. 367 (1947). 
under his consideration. 45 In deciding that the various publications incurred no penalty, the Supreme Court ignored a distinction put forth by both American and English cases..$^{6}$ No judge could be expected to say that he or his colleagues were, or might be, directly influenced to alter their decision by any publication. Yet many judges are willing to admit that some publications may exert the more subtle influence of disturbing the delicate balance of mind without which a calm perusal of the issues is impossible. "A timid man might be influenced to yield, while a combative man would be driven in the opposite direction." 47 The Supreme Court majority, however, omits any reference to the subtle disturbance, and assumes the only evil is the direct effect. It then shows that this latter effect is highly improbable, either because of the "firmness, wisdom, or honor" which must be assumed on the part of the judge, ${ }^{48}$ or because the intimidation exists in the facts themselves and is not enlarged by the stating of them.49 Justice Frankfurter, dissenting, wonders that constitutional doctrine is made of "so questionable a psychological assumption." $5^{\circ}$ Nevertheless, the Court is clear on the point that no punishment for contempt will be allowed because of possible influence upon the judge, short of an actual threat or physical restraint..$^{\mathrm{I}}$ The majority's position will forestall the cases, common in America, in which the judge's chief motivation for exercising the contempt power is resentment at charges of venality or mediocrity..$^{2}$ In addition, it ends the suspension of comment at the

${ }^{45} 314$ U.S. 252, 27 r (r94r).

${ }^{6}$ People v. Wilson, 64 Ill. 195, 2 I $_{4}$ (I872); Rex v. Davies, [1945] K.B. 435, 442.

47 People v. Wilson, 64 Ill. I95, $21_{4}$ ( 1872 ).

$4^{8}$ Bridges v. California, 3 I4 U.S. 252, 273 (I94I). "Judges are supposed to be men of fortitude, able to thrive in a hardy climate." Craig v. Harney, 33I U.S. ${ }^{677,376}$ (x947).

49 Bridges v. California, $3^{14}$ U.S. 252, 278 (I94I).

so Craig v. Harney, 33 I U.S. 367,393 (I947).

sx Dicta implying some limitation on the breadth of the protection can be culled from the majority and concurring opinions. Bridges v. California, 3I4 U.S. 252, 277 (I94I) (Black, J., for the Court: "On no construction, therefore, can the telegram be taken as a threat either by Bridges or the Union to follow an illegal course of action ...."). Craig v. Harney, 33I U.S. 367,376 (r947) (Douglas, J., for the Court: "Conceivably a campaign could be so managed and so aimed at the sensibilities of a particular judge and the matter pending before him as to cross the forbidden line ..."). Tbid., at 377 (Douglas: "But it contained no threat to oppose him in the campaign if the decision on the merits was not overruled, nor any implied reward if it was changed ..."). Ibid. (Douglas: "There was no demand that the judge reverse his position-or else"). Ibid. at 383 (Murphy, J., concurring: "The only possible exception is in the rare instance where the attack might reasonably cause a real impediment to the administration of justice"). Frankfurter, dissenting, feels the majority's rule prevents state courts from acting "except when misbehavior physically prevents proceedings from going on in the court, or occurs in its immediate proximity." Ibid., at $39 \mathrm{I}$.

${ }^{52} \mathrm{As}$ in State v. Tugwell, xg Wash. 238, 52 Pac. 056 (1898). A lyrically insulting criticism of the Supreme Court for reversing its decision was held contemptuous on the ground that the case was still pending because remittitur had not issued. Nelles and King comment on the frequent indications in the opinions that the personal feelings of the judges were aroused. Op. cit. supra note 3 , at 545 . 
termination of the trial, and allows free discussion during the often lengthy period for appeals to higher courts.53

The application of the Supreme Court's formula to the problem of influence upon the parties, witnesses and jury is necessarily speculative because the Court did not discuss these questions. The particular evil to be avoided where parties are concerned is that defendants will be influenced to compromise, and plaintiffs to abandon, their rightful causes. ${ }^{54}$ To avoid this danger the English cases hold that one branch of contempt is an abusive attack upon a party.ss The problem was thought particularly important with respect to stockholder derivative suits, which it is the policy of the law to encourage, yet in which the incentive of the individual plaintiff is likely to be slight. ${ }^{6}$ Regrettably, no study has been discovered of instances in which a private plaintiff or defendant has settled or withdrawn his case because of an unfavorable press. A court presented with the question will have to decide whether the publication presents a clear and present danger of influence of this kind.

The question takes a slightly different form where the party concerned is the public prosecutor. There seems no doubt that he is sensitive to newspaper comment, in securing indictments ${ }^{57}$ as well as in prosecuting the trial. Borchard's dramatic compilation of cases shows that many times one important factor in the erroneous conviction of an innocent man was the blind determination of the district attorney to convict..$^{8}$ In his zeal he overlooked obvious weaknesses in his evidence, which a jury equally imbued with antagonism to the defendant was also unable to see. Newspaper pressure which so hardens the prosecutor's mind that an innocent man is sent to his death is certainly an interference with the fair administration of justice. Whether it is an "extremely serious" interference, and under what circumstances its imminence is "extremely high," are speculative questions which the courts may some day, with the help of psychologists, have to decide.

The English cases suggest that excessive partisan publicity might discourage witnesses as well as parties, or at least influence the testimony they give.s9 The

${ }^{53}$ For example, in the Sacco-Vanzetti case, fully six years elapsed from the entry of judgment in the trial court to the execution of the defendants.

54 In re The William Thomas Shipping Co., Ltd., [1930] 2 Ch. 368, 376; In re Labouchere, I T.L.R. 578, 579 (I90I).

ss Russell v. Russell, rr T.L.R. 38 (r894); Read's and Huggonson's Case, 2 Atk. 469 (1742).

${ }^{6}$ In re The William Thomas Shipping Co., Ltd., [r930] 2 Ch. 368 . The guarantor of debenture stock involved in the derivative action was held in contempt for a published interview which misstated the facts of the case and questioned the plaintiff's motives.

57 A Cleveland study reported that a newspaper campaign to clean up crime was always followed by an increased number of grand jury indictments, many of which were later dismissed for insufficient evidence. The Cleveland Foundation, Criminal Justice in Cleveland 544 (1922).

$5^{8}$ Borchard, Convicting the Innocent xv (x932).

59 Rex v. Blumenfeld, 28 T.L.R. 308 , 3 II (I9I2); In re Labouchere, I7 T.L.R. 578,579 (IgoI); Greenwood v. The Leather-Shod Wheel Co. (Ltd.), I4 T.L.R. 24I (I898); Spurrell v. de Rechberg, II T.L.R. $3^{13}$ (1895). 
testimony of witnesses is a notoriously weak link in the judicial process, carefully hedged about with many safeguards. It is at this weakest point that the effect of publications is likely to be particularly disruptive, both because witnesses are easily discouraged from testifying, inasmuch as they often have no personal interest in the trial, and because memory seems particularly open to suggestion and external pressure. ${ }^{60} \mathrm{~A}$ common situation found by Borchard to result in erroneous conviction is false identity, especially where the accused was presented for identification under circumstances strongly pointing to his guilt. ${ }^{6 x}$ Repeated publication of the defendant's photograph might very easily influence crucial witnesses to identify him as the man they saw at the scene of the crime. The one English court which has considered the problem held the printing of a photograph to be contempt where identity is an issue..$^{62}$ Merely to phrase the application of the clear-and-present-danger test to the witness problem suggests the difficulties the courts will face. They must find that the publication creates the clear and present danger of altering significant testimony which will affect the outcome of the trial.

The English cases provocatively suggest that excessive public discussion might not only influence the parties and witnesses involved in the present action, but might also set a bad example which will discourage future plaintiffs from prosecuting, future defendants from contesting, or future witnesses from testifying. ${ }^{6}{ }_{3}$ Though the argument might have merit, it is difficult to see how the clear-and-present-danger test could reach any other result than to reject it.

The possibility of influence upon the jury raises important and difficult problems. Because of the drama of its role, and its importance in the criminal trial, which much of the agitation for limitation on the press seeks to protect, ${ }^{64}$ the jury is the keystone in the potential development of the American law of contempt. Particular questions involve whether the presumption of. fortitude will apply, how the mind of the jury is prejudiced, what constitutes a "clear and present danger" of such prejudice, what role is played by community attitudes, and whether any distinction should be made before or after the jury is selected.

The earlier discussion showed that the Supreme Court's presumption of "stamina" and "ordinary fortitude" on the part of the judges virtually obliterates any possibility of their being swayed. It seems unrealistic to extend this presumption to the members of the jury. They are neither selected nor trained for their job. The attempt to employ the "blue ribbon" jury has received severe

${ }^{60}$ See Hutchins and Slesinger, Some Observations on the Law of Evidence-Memory, $4 \mathrm{I}$ Harv. L. Rev. 860, 869 (rg28).

6x Borchard, Convicting the Innocent xiii (x932).

62 Rex v. Daily Mirror, [rg27] I K.B. 845. The court first suggests that the publication of the photograph is a contempt "where it is apparent to a reasonable man that a question of identity may arise," but later states that the newspapers "take the risk." Tbid., at 850 .

${ }_{63}$ In re The William Thomas Shipping Co., Ltd., [1930] 2 Ch. $368,374$.

64 Authorities cited note 2 supra. 
criticism in recent years. To equate the stamina of judges and jurors runs counter to one of the basic assumptions of the law of evidence-that jurors must be protected from the undue prejudice of improper evidence upon which, however, the judge may safely pass. ${ }^{65}$ Yet a recent Maryland decision argues that not only are judges human like the rest of mankind, but "it cannot be denied that in every community there are citizens who by training and character are capable of the same firmness and impartiality as the judiciary. It is plainly a matter of degree." ${ }^{16}$ This argument has the weakness that it assumes that only the firm and impartial citizens referred to are ever selected to sit on the jury. If adopted generally as a rule of law, the Maryland court's view will effectively foreclose any significant protection of pending trials.

The danger in publications discussing the trial is either that they will convince the juror one way or the other on the issues, or that they will introduce enough prejudice into his mind that he becomes incapable of giving impartial consideration to the evidence. ${ }^{67}$ What kind of statement is regarded by the court as sufficiently prejudicial will depend on psychological investigations and assumptions. Where the publication contains evidence which would be inadmissible in the trial itself, these still theoretical problems can be by-passed by adopting the assumption of the law of evidence that such prejudice or influence exists. The English courts, ${ }^{63}$ and some American, ${ }^{69}$ hold as a general proposition that the publication of any evidence which would be inadmissible in the trial is a contempt. A court might hold that it is a substantive evil if one or more jurors

6s See 9 Wigmore, Evidence $50 \mathrm{I}$ (I940); Maguire, Evidence-Common Law and Common Sense 202 (1947).

${ }^{66}$ Baltimore Radio Show, Inc. v. State, 67 A. 2d 497, 509 (r949), cert. den. 70 S. Ct. 252 (1950).

67 One observation from a carefully controlled mock trial experiment was that "[e]arly in the trial many jurors reached a fairly definite decision, and ... thereafter the effect of the testimony was merely to change their certainty." Weld and Danzig, A Study of the Way in which A Verdict Is Reached by A Jury, 53 Am. J. of Psych. 5r8, 535 (I940). Newspaper comment which formed such an initial decision would very materially affect the outcome of the trial.

${ }^{68}$ Rex v. Wealdstone News, 4I T.L.R. 508 (1925) (publication of information that defendant in libel action had deposited $£_{50}$ with his solicitors as required by law held contemptuous because it might influence jury on amount of damages); Rex v. Evening Standard, 40 T.L.R. 833 (1924) (findings of amateur detectives); Rex v. Clarke, I03 L.T.R. $6_{3} 6$ (IgIo) (confession, and the purchase of poison sometime before victim's death); Rex v. Tibbits and Windust, [rgo2] I K.B. 77 (IgOr) (reports of Special Crime Investigator).

${ }^{69}$ In Telegram Newspaper Co. v. Commonwealth, 172 Mass. 294, 52 N.E. 445 (I899), the newspaper was held in contempt for publishing the fact that prior to an eminent domain proceeding the town had offered $\$ 80$ compensation but the property owner had asked $\$ 250$. Evidence of offers and counter-offers during pre-trial negotiations is excluded from the trialitself both to encourage voluntary settlement and to avoid unduly influencing the jury on the amount of damages to award. The court in Woodbury v. Commonwealth, 295 Mass. 3I6, 32I, 3 N.E. $2 \mathrm{~d} 779,782$ (1936), referred to the one rule of evidence which would not seem to be applicable to the contempt problem - the rule excluding evidence "related to collateral and extraneous issues." 
read or hear about information the introduction of which into the trial itself would be reversible error. ${ }^{70}$ The recent Maryland case, Baltimore Radio Show, Inc. v. State, involved this problem. ${ }^{7 x}$ Several Baltimore radio stations broadcast that a thirty-one year old Negro had confessed to the brutal stabbing of an eleven year old white girl in a city park, that he admitted to attacking a white woman in the same woods sometime previously, and that he had served eight years in prison for a series of stabbing attacks on women. The court discussed carefully the problem of the prejudicial effect of this evidence..$^{22}$ It pointed out that the introduction of a confession is reversible error only when it was not voluntarily made, and that the defendant's confession was adjudged to have been voluntary. ${ }^{73}$ Again, the court observed that although evidence of past crimes is generally not admissible, there are many exceptions to this rule. Moreover, the court insisted, the exclusion of evidence of past crimes is still a rule of evidence and not a constitutional right. The court's treatment of the psychological assumptions of the two rules of evidence, relating to confessions and past crimes, was strict, but not illogical. Nonetheless, it can be questioned whether the admission of evidence of this kind does not constitute "disorderly administration of justice."

Once having decided that certain kinds of information or other statements are substantially prejudicial, there remains the question of when the danger that they will reach the jury is clear and present. The decision on this question will probably be based on such objective and sociological facts as the volume of circulation and the prestige of the publication, and even on a poll of community opinion.

It is important to realize that the publication can affect the juror indirectly through the formation of community attitudes, as well as directly through his reading or being told about it. Community prejudice can be significant in influencing parties and witnesses as well. A high degree of community antipathy permits change of venue. Mob domination of a courtroom is a denial of due process. 74 Borchard has noted several instances in which strong community hos-

${ }_{70}$ See discussion in I Wigmore, Evidence 394 (1940) of three tests for whether to reverse judgment because of the erroneous admission of evidence. Only the most stringent test would seem to apply to the contempt problem.

7 Note 66 supra. Because of its relation to the jury problem, and because conviction in the trial court was entered under an apparently unique set of court rules defining contempt by publication which had operated successfully for ten years, this decision is probably the most important state application to date of the Supreme Court's clear-and-present-danger test. Other relevant state cases are, Turkington v. Municipal Court, 85 Cal. App. 2d 63I, I93 P. 2d 795 (1948); Robinson v. City Court, I85 P. 2d 256 (I947); Bates v. State, 2ro Ark. 652, I97 S.W. 2d 45 (I946); Kirkham v. Sweetring, I08 Utah 397, r6o P. 2d 435 (1945); Lancaster v. State, 208 Ark. 412, 186 S.W. 2d 673 (I945); Graham v. Jones, 200 La. 137, 7 So. 2d 688 (I942).

${ }^{2}$ Note 66 supra, at 509 -ro.

73 James v. State, 65 A. 2 d 888 (r949).

74 Moore v. Dempsey, 26 I U.S. 86 (1923). 
tility towards the accused was instrumental in securing an erroneous verdict of guilt. ${ }^{75}$ The clear-and-present-danger test with respect to community attitudes will be phrased variously according to the court's definition of the "substantive 'evil" involved. Thus a publication will be found contemptuous which makes a fair trial improbable, highly improbable or impossible. The initialattitudes of the community and the circulation of the publication are relevant facts. But at the center of the analysis lie difficult sociological questions-to what extent do newspapers create community attitudes?-and psychological questions-to what extent do community attitudes affect the mind of the juror? The courts will have to rely on speculation from common experience to reach conclusions, until more reliable and specific studies are made than exist at the present time.

An additional problem is raised with respect to possible influence of jurors which is not posed regarding parties and witnesses. Should any different test of contempt be applied before the jury is chosen than afterwards? Logically, the clear-and-present-danger doctrine seems to require a different test before selection. First, as in the post-selection case, it must be decided that the matter would unduly prejudice one who reads or hears about it. ${ }^{76}$ But secondly, it must be shown that the circulation of the publication is so great as to create a clear and present danger that the selection of twelve untainted jurors will be impossible. ${ }^{77}$ This is a much more stringent demand than the post-selection test requiring a clear and present danger that at least some of twelve known persons will be influenced. ${ }^{78}$ The alternative to using different tests before and after selection of the jury is to apply the post-selection test from the moment the case becomes "pending." This is in effect the English practice. ${ }^{79}$ It is an important reason why it is possible to select impartial jurors more rapidly in England than

75 Borchard, Convicting the Innocent xviii (1932).

${ }^{76}$ With the possible addition of the factor that the prejudice will persist from the day of publication to the first day of argument before the jury.

77 This appears to be the view taken by the Maryland court, for it cites approvingly cases which confront the question whether removal should have been granted because a fair trial was impossible in the locality. Note 66 supra, at 5 IO-II.

${ }^{78}$ For example, assume that "clear and present danger" means an 80 per cent probability. Assume further that there are roo persons qualified for jury duty in the town. Even if it be shown that on the average only 7 of the roo people will be prejudiced by the publication, there is more than 80 per cent probability that at least one of twelve known jurors will be one of these 7. Thus the probability that Juror No. $x$ is one of the 7 is $7 / 100$; that Juror No. 2 is one of the 7 is $7 /$ roo; and so on. The probability that one of the twelve is one of the 7 is the sum of these probabilities, or $12 \times 7 / 100$, which equals 84 per cent. On the other hand, to show that it is 80 per cent impossible to find twelve untainted persons out of the roo we must show that on the average the publication reached 85 of the 100 , instead of only 7 of the 100 (roo minus 85 is $15.12 /{ }_{5}$ equals 80 per cent).

${ }^{79} \mathrm{~A}$ case becomes pending for contempt purposes at least after arrest on warrant. Rex $v$. Clarke, ro3 L.T.R. $63^{6}$ (1910). The "cardinal consideration [is] not that the case has begun, but that it is not at an end. . . . It is possible very effectually to poison the fountain of justice before it begins to flow." Rex v. Parke, [I903] 2 K.B. 432, 438. 
in America. ${ }^{80}$ The English view seems to be the more sensible one. To follow it, however, is to abandon the clear-and-present-danger test for the pre-selection period. ${ }^{8 x}$ Here, as with other difficulties raised by the precise application of the clear-and-present-danger test, the letter of the rule might well be modified in deference to legitimate demands in favor of the fair and orderly administration of justice.

80 Robbins, The Hauptman Trial in the Light of English Criminal Procedure, 2r A.B.A.J. 301 (1935); Lawson and Keedy, Criminal Procedure in England, r J. Crim. L. \& C'gy. 595, 748 , at $6 \mathrm{II}$ ( $\mathrm{rgII}$ ). The American examination of prospective jurors on voir dire is of dubious value in eliminating prejudice. See the caustic observation of the trial judge in the Baltimore case: "Well, now, it hardly seems necessary for the Court to say to men who are experienced in the trial of jury cases, that every time Defense Counsel asked a prospective juror whether he had heard a radio broadcast to the effect that his client has confessed to this crime or that he had been guilty of similar crimes, he would by that act be driving just one more nail into James' coffin." Maryland v. Baltimore Radio Show, Inc., 7o S. Ct. 252, 254 (x950).

8x Unless the "substantive evil" is redefined as, for example, that twelve impartial jurors cannot be selected by ordinary voir dire methods. 